\title{
Absence of National Culture in Foreign Language Teaching and Intercultural Communication Competence Training of College Students in China Frontier Minority Areas
}

\author{
Jinan $\mathrm{Jia}^{1}$ \\ ${ }^{1}$ School of Foreign Languages, Inner Mongolian University for Nationalities, China \\ Correspondence: Jinan Jia, School of Foreign Languages, Inner Mongolian University for the Nationalities, \\ Tongliao, China. E-mail: jiajinan@imun.edu.cn
}

Received: January 4, 2015 Accepted: February 6, 2015 Online Published: March 25, 2015

doi:10.5539/elt.v8n4p52 URL: http://dx.doi.org/10.5539/elt.v8n4p52

\begin{abstract}
The absence of Chinese culture in foreign language teaching has a strong impact on the exchange between different cultures, and is also an obstacle to intercultural communication competence training. In general, English teaching level in China frontier minority areas is far behind that in developed areas, and shows its own teaching and cultural characteristics. In this paper, the composition of intercultural communication competence, the absence of foreign language teaching culture of college students in China frontier minority areas and the strategy of improving intercultural communication competence of college students were discussed. The characteristics of intercultural communication competence of college students in China frontier minority areas and the law of their intercultural communication competence training were then investigated in depth.
\end{abstract}

Keywords: absence of national culture, intercultural communication competence, training

\section{Introduction}

"Chinese culture aphasia" was first proposed by Professor Cong Cong of Nanjing University in his article "Chinese Culture Aphasia: Defects of English Teaching in China" published in Guangming Daily in 2000. He argued that the absence of Chinese culture in foreign language teaching, i.e. "Chinese culture aphasia", greatly influenced the exchange between different cultures and became an obstacle to intercultural communication. His opinions caught the attention of educational circles, and many scholars in foreign language teaching conducted empirical studies on this phenomenon. Zhang (2007) expressed her ideas in Intercultural Foreign Language Teaching, i.e. the unidirectional import of western culture was unable to meet the social demand for foreign language talents, the English expression of Chinese culture had not been taken into account in cultural teaching of foreign language teaching, and the current resources including teachers, teaching materials and teaching methods were incapable of meeting the demand of cultural learning; therefore, it was no wonder that "aphasia" occurred. In Chinese Culture in College English Teaching published by Zhang Weimin and Zhu Hongmei, test methods were used to prove that most participants could not express their national culture fluently. Wei (2009), in his Review of Absence of Chinese Culture in Foreign Language Teaching, investigated the current situation, cause, hazard and solutions regarding absence of Chinese culture in foreign language teaching, and believed that it is necessary to strengthen the awareness of students of native language culture and improve their intercultural communication competence; in addition, foreign language teaching should not only focus on the import of target language culture, but also enhance the inheritance and spread of native language culture, so as to promote national culture and spread international culture. The above studies show that Chinese culture aphasia in foreign language teaching has formed an obstacle to intercultural communication competence training. In this paper, the composition of intercultural communication competence, the current situation regarding absence of foreign language teaching culture of college students in frontier minority areas and the strategy of improving intercultural communication competence of college students were discussed.

\section{Composition of Intercultural Communication Competence}

Foreign scholars have discussed intercultural communication competence. Kim (1991) and Gudykunst (1992) believed that intercultural communication competence includes the adaptability in aspects such as cognition, emotion, and behavior. Fantini (1995) divided intercultural communication competence into five elements and 
described it in many ways to help educators know its connotation, in which knowledge, positive attitudes, skills and awareness are the core of intercultural communication competence. Zhang (2007), based on research results of other scholars including Samovar and Porter (1995); and Byram (1997), proposed a framework of intercultural communication competence including attitude, knowledge and behavior. The primary goal at attitude level is to enhance self-awareness, understand ethnocentrism and stereotype and eliminate prejudice. Whereas the primary goal at knowledge level is to accumulate the knowledge of national culture and foreign culture and compare them to know their differences and similarities, the primary goal at behavior level is to reflect on national culture and individual intercultural interaction. Yang and Zhuang (2007) proposed a framework of intercultural communication competence regarding foreign languages, including global awareness, cultural adaptation, and knowledge and communication practice. Global awareness is the most fundamental part of intercultural communication competence, as well as the complex of intercultural awareness and intercultural thinking. The intercultural awareness in intercultural communication competence represents how people perceive themselves, their national culture as well as foreign cultures. Intercultural thinking covers the abilities to analyze, integrate, compare and generalize cultural phenomenon. To sum up, ntercultural thinking consists of the ability of cultural understanding and the ability of cultural analysis. The ability of cultural understanding is to understand the difference of communicative behavior of people from different cultural backgrounds, and find the cultural cause that generates difference; the ability of cultural analysis is to compare the national culture and the foreign culture and summarize their differences and similarities. Therefore, a qualified intercultural communicator should understand the knowledge of foreign communication culture without ignoring the significance of learning national culture.

\section{Absence of Foreign Language Teaching Culture of College Students in China Frontier Minority Areas}

The Chinese Ministry of Education issued the English Teaching Syllabus for English Majors in 2000, which emphasized that it is important to train English talents with extensive cultural knowledge. The extensive cultural knowledge should include the national culture represented by English (English culture) and Chinese culture. In accordance with the Syllabus, in the teaching program for English majors, the courses regarding the overview of western culture and Chinese culture are required to offer, the purpose of doing so is to help students master the essence of Chinese and western culture, train their sensibility and tolerance for cultural difference and flexibility in dealing with cultural difference, and train their critical thinking in absorbing the essence of world culture and inheriting and promoting excellent culture in China. In 2004, the Chinese Ministry of Education published the College English Curriculum Requirements, and emphasized that the comprehensive cultural literacy of college students should be improved to be adapted to the demand of China's economic development and international exchange. In view of the difference of higher education nationwide, the requirements in college English teaching are divided into three levels, in which the highest level includes the ability to translate articles that introduce China's actual conditions and culture, absorb the essence of world culture, and inherit and promote the excellent culture in China. However, the reality of English teaching requires fundamental courses and optional courses which take British and American culture as their background. In addition, core content are provided almost in every college, but little content involves Chinese culture and customs. Currently, college English courses only emphasize learning cultural knowledge, value orientation, aesthetic standard, moral concept and outlook on world and life from western countries. Hence, the primary purpose of students' English learning is to master English communication skills; and English teaching does not assume the responsibility of transmitting Chinese culture, and disregards or even abandons the excellent traditional culture and national culture in China.

College English teaching in frontier minority areas has both the common characteristics in general education nationwide and its unique features due to the effect of special culture and custom of regional ethnic minorities. Moreover, the unique ethnic culture background, education, living environment and language thinking model make the process of English teaching in minority areas even more difficult. In the Studies on the Native Culture Input in English Education of Local Universities and Colleges in Minority Regions, Peng (2012) proposed that the localization of college English education in minority areas is to help learners absorb the cultural essence of English-speaking countries and protect the deposits of their ethnic culture, or in other words, it is a process of integrating intercultural concepts into English education, where localized education should be based on the respect of the culture of English-speaking countries, and implement the integrated intercultural education in a purposeful and planned way.

However, the reality of foreign language teaching fails to meet expectations. The Questionnaire on Current Situation and Attitude of Cultural Expression in Mongolian shows that almost half of students focused on Mongolian culture, and half of students held a positive attitude on the expressing Mongolian culture by foreign language. The students were generally unable to express Mongolian culture by foreign language. Moreover, most 
of the students agreed that Mongolian culture could be obtained during foreign language learning, but the reality was that less information about Mongolian culture was involved in foreign language teaching materials. Furthermore, teachers seldom included Mongolian culture in classroom teaching. Consequently, students could only acquire relevant knowledge from very limited resources such as books, newspapers, magazines and Internet. Half of students thought that the best way to introduce Mongolian culture during teaching was to offer the second classroom. However, in reality, due to the long term economic backwardness and low material standard of living in frontier minority areas, the English teaching there is far behind that in central China, and its disadvantages include fewer chances and frequency of communicating with foreigners, shortage of language application in intercultural communication, and shortage of reflection on intercultural communication competence training of students in real life. Other typical problems of college English teaching in minority areas include a) low-quality source of students; b) relatively monotonous teaching model; c) and deficiency of network resources for self-study and teaching. Therefore, a majority of students believed that the lack of linguistic competence is the primary reason that influences intercultural communication, and the second one is the effect of cultural knowledge.

\section{A Strategy for Improving Intercultural Communication Competence of College Students in Minority} Areas

\subsection{Improve the Awareness on Culture of the Self}

The intercultural awareness in intercultural communication competence represents how people perceive themselves, their national culture as well as foreign cultures. In short, "the basis of intercultural communication starts from knowing oneself" (culture and cultural consciousness). The present paper holds that the significant shortage of national culture in foreign language teaching is a representation of the lack of awareness on culture of the self. The primary condition for inheritance of national culture should be cultural consciousness. Fei (2010), a well-known Chinese anthropologist, proposed the concept of "cultural consciousness", i.e. a group of people in certain culture should know the origin, formation, features and development trend of the culture itself. He also believed that cultural consciousness is a tough process, and an individual can only establish his/her position in the ongoing multi-culture world based on the knowledge of his/her culture and a variety of other cultures. The training of intercultural communication competence should be first a problem of intercultural awareness, i.e. a problem at the attitude level. The foreign language teaching in college in Mongolian regions should take the initiative to a) play the fundamental role in cultural inheritance and innovation; b) integrate the inheritance of national culture and the training of intercultural communication competence; c) train the intercultural communication competence of students; and d) serve local economy and society.

\subsection{Enhance the Accumulation of Local National Culture}

The knowledge level in the construction of intercultural communication competence is intended to accumulate the knowledge of national culture and foreign culture and compare them to know differences and similarities between them. People usually have some misunderstanding during foreign language teaching, i.e., intercultural communication is to understand the knowledge of western culture and communicate with westerners in English. As a result, the input of western culture is overestimated while the output of Chinese culture was ignored or even abandoned. In this respect, the equality in cultural exchange is overturned, and people lack the sense of equality in cultural exchange; and have inadequate knowledge of exchange interaction. Consequently, the local culture gradually loses its voice in international cultural exchange, and the balance between Chinese and Western culture is tipped. In the Cultural Globalization and Intercultural Dialogue: Intercultural Communication Research from a Global Perspective, Jia (2009) argued that intercultural communication in the context of cultural globalization should adhere to the concept of harmony in diversity. The term diversity refers to the uniqueness of national/local culture as well as the difference and diversity of culture, while "harmony" means globalization. The "dialogue" in this context presupposes equality and difference. Equal "dialogue" is represented by interaction and reciprocity, exceeding differences and similarities, expanding the common ground, extending the self and expanding cultural identity in different cultural levels such as individual, gender, region, religion, nationality, country and internationality, on the condition that the orientation of ethnic culture is retained. As said by Fei Xiaotong, different cultures should appreciate their own beauty, tolerate the beauty of others and then integrate their own beauty and the beauty of others to achieve the Great Harmony. The Mongolian culture featured by born and brought up in the same place is a part of China's multi-culture consisting of various local cultures in different regions. It has a long history, and is elegant and magnificent. As a result, less information about Mongolian culture was involved in foreign language teaching materials and teachers seldom included Mongolian culture in classroom teaching. Thus, it is necessary to make the most of the memorable characters (such as Gada Meiren), traditional virtues, good customs and other local cultural elements 
in minority areas; and compare these elements with western culture in daily English teaching. Therefore, the excellent local national culture can be accumulated in a conscious and positive way, and the in-depth understanding on national culture can enhance national dignity, confidence and pride of students.

\subsection{Create Training Methods of Intercultural Communication Competence}

The goals at the level of attitude and knowledge can be practically significant only after being transformed into behavioral skills. If they remain at the level of cognition and emotion, it is likely to expand the scope of knowledge and change attitude at most. The all-round improvement of intercultural communication competence is a mere phrase. However, the foreign language teaching in China has been influenced by exam-oriented education for a long time. As the survivors in this education system, the students usually have rich linguistic knowledge, but suffer from pragmatic failure and cultural problem. Due to regional differences, the frontier minority areas are relatively closed compared with developed areas, and provide limited chances for foreign exchange. As a result, teachers and students in minority areas have fewer opportunities to achieve effective intercultural communication, and are relatively disadvantaged in sensitivity and competence of intercultural communication. Foreign language teaching is not the only way to train intercultural communication competence, but it provides a huge potential and significant advantage for training intercultural awareness and intercultural communication competence. Therefore, the English teaching in minority areas should respond to the following questions: a) how can teachers' intercultural literacy be trained on the basis of improvement of practical teaching ability? b) how can the local cultural elements be integrated with English teaching? and c) how can more practices be created in limited realistic conditions so as to improve the intercultural sensitivity and intercultural communication competence of teachers and students? Concerning the college where the present author works, the paper suggests that courses regarding national culture should be added on the basis of the original curriculum system. For example, it is necessary to offer some elective courses like Translation of National Culture and Comparison of National Culture. The time-honored and gorgeous national culture resources such as Naadam and Mongolian Wrestling should be applied in teaching, and the original teaching content should be integrated. The effect of national culture should be enhanced by virtue of situational teaching method, infiltration teaching method, participatory teaching method and the open classroom. The teaching content of foundation teaching of the foreign language - teaching of Chinese and Western culture - local cultural teaching should be set up in the foreign language class to achieve the three-dimension cultural teaching. Moreover, in view of regional reality, it is also necessary to a) let students walk out of virtual learning environment by social practice to acquire characteristic national culture, experience and knowledge in the real situation; b) help them participate in research and translation of national culture; and c) and train their intercultural communication competence and the ability to acquire, inherit and promote national culture in intercultural communication.

\section{Conclusions}

Driven by cultural globalization and China's modernization, a brand-new image of China is being created internationally in the new century. Intercultural awareness and intercultural communication competence are the teaching goals put forward by educational circles of foreign languages (or English as a foreign language) in recent years, while cultural inheritance is the important value goal that intercultural teaching pursues. Therefore, the training of students' awareness of cultural inheritance is closely related to the training of intercultural communication competence. From the perspective of foreign language teaching, the training of cultural inheritance competence for college students in minority areas should also follow this direction. This paper started with intercultural communication and Chinese culture aphasia in English teaching of regional colleges for nationalities, and investigated the characteristics of constructing intercultural communication competence of college students in frontier minority areas and the law of their intercultural communication competence training. In a more concrete sense, the research results are able to a) widen the horizon of intercultural communication research in minority areas; b) enrich the content of college English teaching reform in minority areas; c) innovate college English teaching model in minority areas; and d) provide the basis of feasibility and reform thinking.

\section{Acknowledgements}

This paper is one of the phased achievements of the author for his teaching research project "Study on Case analysis Teaching Applied in Intercultural Communication Courses". Project No. MDZD 201409.

\section{References}

Chen, X. J. (2010). Two-way of Cultural Transmission in Cross-Cultural Communication. Journal of Jilin Engineering Technical Teachers College, 4(54).

Cong, C. (2000). Chinese Culture Aphasia: Defects of English Teaching in China. Guangming Daily, 10(10). 
Fantini, A. E. (1995). Language, Culture, and World View: Exploring the Nexus. International Journal of Intercultural Relations, 19, 143-153.

Fei, X. T. (2010). Culture and Cultural Consciousness (p. 195). Beijing: QunYan Press.

Jia, Y. X. (2009). Cultural Globalization and Intercultural Dialogue: Intercultural Communication Research from a Global Perspective. Beijing: Higher Education Press.

Peng, Q. (2012). Local Culture Input of Colleges English Education in National Regions. Journal of Hebei United university, 1(56-57).

Wei, H. J. (2009). The Research of Lack of Chinese Culture in Foreign Language Teaching. Journal of Cultural, $4(49-51)$.

Xu, L. S. (2000). The Study of Cross-Cultural Communicative Competence. Foreign Language and Foreign Language Teaching, 7(19).

Yang, Y., \& Zhuang, E. P. (2007). Cross-Cultural Communication Ability in Foreign Language Teaching Framework. Language World, 4(15-17).

Zhang, H. L. (2007). Cross-cultural Communication and Foreign Language Teaching (pp. 68-73). Shanghai: Shanghai Foreign Language Education Press.

\section{Copyrights}

Copyright for this article is retained by the author(s), with first publication rights granted to the journal.

This is an open-access article distributed under the terms and conditions of the Creative Commons Attribution license (http://creativecommons.org/licenses/by/3.0/). 